\title{
DESCRIPTIONS OF FOUR NEW SHELLS FROM THE PERSIAN GULF AND BAY OF ZAILA.
}

\author{
By G. B. Sowerby, F.L.S., ete. \\ Read June 8th, 1894.
}

PLATE XII. Figs. 20, 23, 25, 26.

1. Cancellaria paucicostata, n.sp. Pl. XII. Fig. 26.

Testa angulata, utrinque conica, vix umbilicata, pallide fulva, obscure fuseo fasciata; spira conica, gradata, mediocriter elevata; anfractus 6, convexi, embryonales læves, sequentes obtuse angulati, longitudinaliter costati, liris numerosis confertis angustis alterne crassioribus eximie lamellatis spiraliter sculpti; anfractus ultimus costis paucis irregularibus instructus; apertura latiuscula, subtrigonalis, labrum leviter arcuatum, fuseo tinctum; columella rectiuscula, triplicata. Long. 17 , lat. $11.50 \mathrm{~mm}$.

Hab.-Persian Gulf.

An exquisitely sculptured shell, in which the angle of the bodywhorl is lower than in the prevailing forms of the genus. The ribs on the body-whorl are few and irregularly placed. It would be difficult to assign the sectional or sub-generic position of this species, according to Dr. Jousseaume's arrangement. In form it seems intermediate between Euclia, H. and A. Adams, and Scalptia, Jousseaume; it has also some affinity with Trigonostoma, Blainville, as represented by $C$. costata, Gray, though it wants the umbilicus.

2. Ancilla (Monoptygma) unidentata, n.sp. Pl. XII. Fig. 20.

Testa oblongo subovata, crassa, polita, nitens, pallide fuscescens, hic illic castaneo strigata, postice castaneo latifasciata; spira exserta, obtusiuscula, callosa; apertura oblonga, postice angustiuscula, antice latior, truncata; labrum læve, crassiusculum; columella antice leviter contorta, plicata, postice callosa, plica unica dentiformi instructa. Long. 6, lat. $3 \mathrm{~mm}$.

Hab.-Bay of Zaila.

A bright shining little shell, of which the spire is covered with a dark-brown enamel. It forms the second recent species of Lea's genus Monoptygma, characterized by a tooth-like plica above the middle of the columella.

3. Nassa Zamlensis, n.sp. Pl. XII. Fig. 25.

Testa acuminato-ovata, crassa, rugosa, griseo-albida, nigro-fusco fasciata; spira elata, acuta; anfractus 8, convexi, spiraliter subtilissime striati, costis numerosis nodulosis albo-articulatis instructi, nodulis obtusis, confertis; anfractus ultimus ventricosus, supra sulca latiuscula divisus; apertura subovata, intus costata, nigro-fusco fasciata, canali brevissimo; labrum politum, latiusculum, album, fusco pictum ; columella brevis, alba, plicata, antice contorta. Long. 15, maj. lat. $8 \mathrm{~mm}$. 
Hab.-Bay of Zaila.

A prettily marked shell, in form somewhat like $N$. vibex, Say (sub-genus Phrontis, H. and A. Ad.).

4. Donax Townsendi, n.sp. Pl. XII. Fig. 23.

Testa sub-trigono oblonga, compressa, cuneata, valde inæquilateralis, polita, obscurissime radiatim striata, luteo-fusca, fasciis purpureis fuscisque irregulariter picta; umbones acuti; margo dorsalis anticus rectiusculus, declivis, posticus truncatus, angulo postico obtusiuseulo; area postangulari, bipartita, dimidio radiatim lirato, liris numerosis acutis hic illic clathrato, deinde laminis concentricis acutis laciniatis sculpta; pagina interna purpurea. Longit. 26, alt. $15 \cdot 5 \mathrm{~mm}$.

Var. a. Intus extusque lutea, postice pallide purpureo tincta.

Hab.-Persian Gulf.

This pretty species varies considerably in colour, the interior of the type being dark purple; some specimens are yellow within, and some nearly white, but these nearly all have a tinge of purple at the posterior end. The sculpture of the posterior area is rather peculiar, half the space behind the angle having sharp radiating liræ, and the other half concentric fringed laminæ, which, however, in most specimens more or less overlap the liræ, producing here and there a latticed sculpture.

\section{EXPLANATION OF PLATE XII.}

Fig. 1. Columbella (Amycla) planaxiformis.

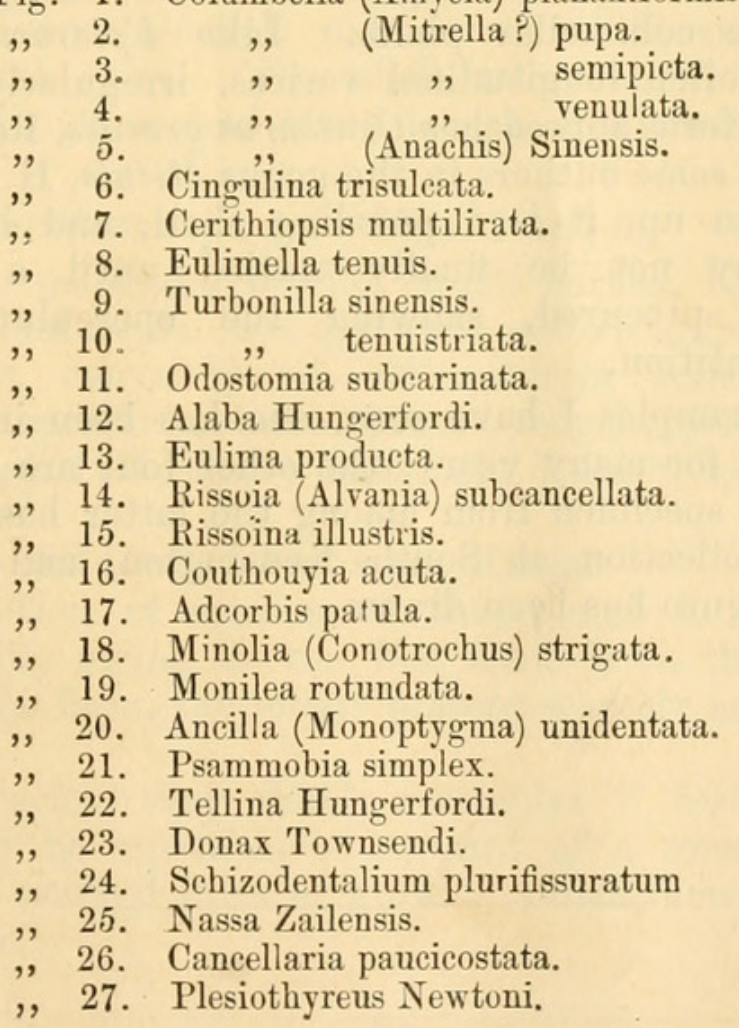




\section{$2 \mathrm{BHL}$ Biodiversity Heritage Library}

Sowerby, G. B. 1894. "DESCRIPTIONS OF FOUR NEW SHELLS FROM THE PERSIAN GULF AND BAY OF ZAILA." Proceedings of the Malacological Society of London 1, 160-161.

View This Item Online: https://www.biodiversitylibrary.org/item/52295

Permalink: https://www.biodiversitylibrary.org/partpdf/202586

\section{Holding Institution}

Smithsonian Libraries

\section{Sponsored by}

Smithsonian

\section{Copyright \& Reuse}

Copyright Status: Public domain. The BHL considers that this work is no longer under copyright protection.

This document was created from content at the Biodiversity Heritage Library, the world's largest open access digital library for biodiversity literature and archives. Visit BHL at https://www.biodiversitylibrary.org. 